\title{
Psychological and Social Determinants of HIV: Path Analysis Evidence from Jepara, Central Java
}

\author{
Ita Fijanah Puspita1), Uki Retno Budihastuti²), Vitri Widyaningsih3) \\ ${ }^{1)}$ Masters Program in Public Health, Universitas Sebelas Maret \\ ${ }^{2)}$ Department of Obstetrics and Gynecology, Dr. Moewardi Hospital \\ 3)Faculty of Medicine, Universitas Sebelas Maret
}

\begin{abstract}
Background: HIV/AIDS was a global problem as a challenge in health discipline and a very important burden of disease to be addressed. Moreover, it had high mortality. This study aimed to analyze the risk factors for HIV/AIDS infection.

Subjects and Method: This was a case control study conducted in Jepara, Central Java, from April to May 2019. A sample of 200 study subjects was selected by fixed disease sampling. The dependent variable was HIV/AIDS. The independent variables were age, gender, unsafe sex behavior, sexual orientation, frequency of intercourse, injection drug abuse, social capital, perceived susceptibility, perceived seriousness, perceived threat, self-efficacy, and geographical location. The data were obtained from medical record and questionnaire. The data were analyzed by path analysis.

Results: HIV / AIDS had a direct relationship with the frequency of sexual intercourse $(b=1.23$; $95 \% \mathrm{CI}=0.27$ to $2.19 ; \mathrm{p}=0.012)$, injecting drug use $(\mathrm{b}=2.19 ; 95 \% \mathrm{CI}=0.01$ to $4.37 ; \mathrm{p}=0.049)$, behavior unsafe sex $(b=3.10 ; 95 \% C I=2.21$ to $3.99 ; p<0.001)$, and sexual orientation $(b=3.69$; $95 \% \mathrm{CI}=1.35$ to $6.04 ; \mathrm{p}=0.002$ ). HIV / AIDS had an indirect relationship with perceptions of threats, gender, geographical location, social capital, perceptions of vulnerability, perception of seriousness, self-efficacy, and age.

Conclusions: HIV / AIDS has a direct relationship with the frequency of sexual relations, sexual orientation, unsafe sexual behavior, and injecting drug use. HIV / AIDS has an indirect relationship with age, gender, perception of vulnerability, perception of seriousness, perception of threats, self-efficacy, social capital, and geographical location.
\end{abstract}

Keywords: HIV / AIDS, sexual behavior, social capital, path analysis

\section{Correspondence:}

Ita Fijanah Puspita, Masters Program in Public Health, Universitas Sebelas Maret. Jl. Ir. Sutami 36A, Surakarta 57126, Central Java. Email: itapuspita713@gmail.com. Mobile: o81347970482.

\section{BACKGROUND}

HIV / AIDS was a public health problem that required serious care all over the world. Globally 36.9 million people lived with HIV and 1.8 million with new HIV cases. Also 940,000 people died from AIDS and 35.4 million people have died from AIDS since the beginning of the epidemic. $14 \%$ of the 630,000 people with HIV in Indonesia have access to antiretroviral therapy (WHO, 2018).
Cases of HIV/AIDS in Jepara Regency from January to June 2017 reached 58 cases and in September 2017 the number of findings increased to 113 cases. This put Jepara Regency as the second city for the most new finding of HIV/AIDS in Central Java under the City of Semarang. The cases of HIV/AIDS in Jepara in 2016 were 118 cases. This number increased by 231 cases in September 2017 or $27.6 \%$ from 834 cases of findings from 1997 to September 2017. There were 169 new HIV cases from 
Journal of Health Promotion and Behavior (2019), 4(1): 43-54

https://doi.org/10.26911/thejhpb.2019.04.01.05

January to December 2018 including 70 cases of housewives, 9 female sex workers, 20 workers cases, 57 cases of entrepreneurship, 3 cases of fishermen, 3 cases of drivers, and 7 cases of under-fives (Jepara District Health Office, 2018).

Behaviors and conditions that place individuals at greater risk of contracting HIV included unprotected anal or vaginal sex, having other sexually transmitted infections such as syphilis, herpes, chlamydia, gonorrhea, and bacterial vaginosis, sharing contaminated needles, syringes and other injection equipment, alternating injecting drug use, receiving unsafe injections, blood transfusions, tissue transplants, medical procedures involving non-sterile cuts or punctures, and accidental needling injuries, including among health workers (WHO, 2018).

Sionean et al. (2014) stated that HIV/AIDS infection risk factors included having unprotected vaginal sex with one or more opposite sex in the last 12 months before condom examination and anal sex with one or more opposite sex partners. The majority of respondents used non-injection drugs within 12 months before the interview and one in seven participants used cocaine.

Factors related to sexual behavior which were at risk for HIV infection among the 15-19 year age group included gender, single orphans, and employment. While the age of 20-24 years, factors related significantly included gender, education level, relationship with the head of the household, place of residence, and risk of pregnancy (Gon-zález et al., 2019).

Psychosocial factors were important as strategies to reduce the spread and risk behavior of HIV/AIDS. Psychosocial health problems were factors that have a significant relationship with risky behavior, such as depression damaging physical and cognitive functions. Therefore, it could inter- fere the decision to conduct safe sexual behavior (Gemechu et al., 2013).

Social capital is a potential construct as an understanding of health inequalities based on individual and community level factors between health care facilities and health program outcomes (Cené et al., 2011).

Social capital had been identified in Indonesia. Social capital produced several theoretical models as potential determinants that influence the prevention and transmission of Human Immunodeficiency Virus (HIV) at the individual and population level. However, the influence between social capital and HIV still gets limited attention (Ransome et al., 2018).

Impacts caused when a person has infected with HIV infection included income lost due to death or full inability to work, loss of income due to partial inability to work due to AIDS, additional care work in AIDS-affected households, additional work carried out by children in households affected by AIDS, impaired children's education children living in AIDS-affected households (International Labor Office, 2018).

Based on the description above, authors were interested in conducting a study on "Psychological and Social Determinants of HIV: Path Analysis Evidence from Jepara, Central Java".

\footnotetext{
SUBJECTS AND METHOD

\section{a. Study Design}

This study was conducted using analytic observational models with a case control approach carried out in the work area of Jepara District Health Office in April - May 2019.

\section{b. Population and Samples}

The target population of this study was all residents of Jepara Regency, Central Java who had conducted VCT examinations from
} 
January to December 2018. A sample of 200 study subjects was selected by fixed disease sampling. The case group in this study was positive HIV/AIDS and the control group were who had undergone VCT examinations and negative HIV / AIDS.

\section{c. Study Variables}

The dependent variable was HIV/AIDS infection. The independent variables were age, gender, unsafe sex behavior, frequency of sexual relations, sexual orientation, geographic location, social capital, injection drug use, perceived susceptibility, perceived seriousness, perceived threat, and selfefficacy.

\section{d. Operational Definition of Variables HIV/AIDS infection. HIV/AIDS was an} infection caused by Human Immuno deficiency virus. The data were obtained from Jepara district fealth office. The measurement scale was categorical.

Age. Age was the age of the subjects when first diagnosed with HIV. The data were collected by questionnaire. The measurement scale was continous, but for data analysis, it was transformed into dichotomous.

Gender. Gender was adaptation or division of biologically determined two genders that were inherent in a particular gender. The data were collected by questionnaire. The measurement scale was categorical.

Geographical location. The geographical location was where a subject lives in a subdistrict near the port or far from the port. The data were collected by questionnaire. The measurement scale was categorical.

Sexual orientation. Sexual orientation was emotional and sexual attraction to certain gender. The data were collected by questionnaire. The measurement scale was categorical (homosexual or heterosexual).

Social capital. Social capital was a characteristic of the community which included social organization, citizen participation, norms of reciprocity, and mutual trust between community members that facilitate cooperation to achieve mutual benefits. The data were collected by questionnaire. The measurement scale was continous, but for data analysis, it was transformed into dichotomous.

Injection drug use. Injecting drug use means that a subject that has used injecting drugs or not before being diagnosed with HIV/AIDS. The data were collected by questionnaire.. The data measurement scale was categorical.

Perceived susceptibility. Perceived susceptibility was a subjective perception of someone about the risk of contracting a disease, and the possibility that was felt refers to the risk of someone suffering from certain diseases or adverse health effects. The measurement scale was continous, but for data analysis, it was transformed into dichotomous.

Perceived seriousness. Perceived seriousness was defined as perception of the severity of the disease or let it not be treated according to circumstances or actions that might occur. The measurement scale was continous, but for data analysis, it was transformed into dichotomous.

Perceived threat. Perceived threat was a situation where individuals perceive a situation as a negative situation and feel the need to protect themselves. The data were collected by questionnaire. The measurement scale was continous, but for data analysis, it was transformed into dichotomous.

Self-efficacy. Self-efficacy was the belief in the ability of the respondent's self about the risk of transmission or the risk of HIV / AIDS that they suffer. The data were collected by questionnaire. The measurement scale was continous, but for data analysis, it was transformed into dichotomous.

Unsafe sex behavior. Unsafe sex behavior referred to a behavior that arised because there was a sexual drive that was 
Journal of Health Promotion and Behavior (2019), 4(1): 43-54

https://doi.org/10.26911/thejhpb.2019.04.01.05

done improperly without the use of safety. The data were collected by questionnaire. The measurement scale was continous, but for data analysis, it was transformed into dichotomous.

\section{e. Data Analysis}

Univariate analysis aimed to explain each variable namely the independent variable and the dependent variable. Bivariate analysis was conducted using chi-square test. Path analysis was conducted to examine direct and indirect effects between independent and dependent variables. Stages of path analysis included model specification, model identification, model fit, estimation, and model re-specification.

\section{f. Research Ethics}

Research ethics included anonymity, confidentiality, informed consent, and research ethics. Research ethics was obtained from Research Ethics Committee Dr. Moewardi hospital, Surakarta, Central Java, with the number: 446 / III / HREC / 2019.

\begin{tabular}{l}
\hline \multicolumn{1}{c}{ RESULTS } \\
\hline 1. Univariate Analysis \\
The results of the univariate analysis des- \\
cribed in Table 1 and Table 2.
\end{tabular}

Table 1. Sample Characteristics (continuous data)

\begin{tabular}{lccccc}
\hline \multicolumn{1}{c}{ Variable } & N & Mean & SD & Minimum & Maximum \\
\hline Age (year) & 200 & 35.38 & 8.77 & 19 & 55 \\
Unsafe sex behavior & 200 & 16.23 & 3.01 & 12 & 25 \\
Social capital & 200 & 35.38 & 4.88 & 18 & 44 \\
Perceived susceptibility & 200 & 33.81 & 2.90 & 27 & 40 \\
Perceived severity & 200 & 61.11 & 4.65 & 50 & 72 \\
Perceived threat & 200 & 94.91 & 5.90 & 80 & 109 \\
Self-efficacy & 200 & 38.04 & 3.63 & 27 & 49 \\
\hline
\end{tabular}

Tabel 2. Sample Characteristics (categorical data)

\begin{tabular}{llcc}
\hline Characteristics & & (n) & (\%) \\
\hline Age & $<36$ years & 102 & 51.0 \\
Gender & $\geq 36$ years & 98 & 49.0 \\
HIV/AIDS Infection & Male & 88 & 44.0 \\
& Female & 112 & 56.0 \\
Unsafe Sex Behavior & No & 117 & 58.5 \\
& Yes & 83 & 41.5 \\
Frequency of having sex & Safe & 99 & 49.5 \\
& Unsafe & 101 & 50.5 \\
Sexual Orientation & $1-3$ times/week & 157 & 78.5 \\
Social Capital & $\geq 4$ times/week & 43 & 21.5 \\
& Heterosexual & 184 & 92.0 \\
Perceived susceptibility & Homosexual & 16 & 8.0 \\
Perceived severity & High & 120 & 60.0 \\
Perceived threat & Low & 80 & 40.0 \\
Self-Efficacy & High & 129 & 64.5 \\
Injection drugs abuse & Low & 71 & 35.5 \\
& High & 102 & 51.0 \\
Geographical Location & Low & 98 & 49.0 \\
& High & 105 & 52.5 \\
& Low & 95 & 47.5 \\
& High & 131 & 65.5 \\
& Low & 69 & 34.5 \\
& Yes & 10 & 5.0 \\
& No & 190 & 95.0 \\
& Close to the coast / port & 30 & 85.0 \\
\hline
\end{tabular}


Table 3. The results of bivariate analysis

\begin{tabular}{|c|c|c|c|c|c|c|c|c|}
\hline \multirow{3}{*}{ Independent Variables } & \multicolumn{4}{|c|}{ HIV/AIDS } & \multirow{2}{*}{\multicolumn{2}{|c|}{ Total }} & \multirow{3}{*}{ OR } & \multirow{3}{*}{$\mathbf{p}$} \\
\hline & \multicolumn{2}{|c|}{ No } & \multicolumn{2}{|c|}{ Yes } & & & & \\
\hline & $\mathbf{N}$ & $\%$ & $\mathbf{N}$ & $\%$ & $\mathbf{N}$ & \% & & \\
\hline \multicolumn{9}{|l|}{ Age } \\
\hline$<36$ years & 64 & 62.7 & 38 & $37 \cdot 3$ & 102 & 100 & \multirow{3}{*}{1.43} & \multirow[t]{3}{*}{0.214} \\
\hline \multirow{2}{*}{\multicolumn{7}{|c|}{ Gender }} & & \\
\hline & & & & & & & & \\
\hline Male & 52 & 59.1 & 36 & 40.9 & 88 & 100 & \multirow[t]{2}{*}{1.04} & \multirow[t]{2}{*}{0.886} \\
\hline Female & 65 & 58.0 & 47 & 42.0 & 112 & 100 & & \\
\hline \multicolumn{9}{|l|}{ Frequency of having sex } \\
\hline 1-3 time/week & 102 & 65.0 & 55 & 35.0 & 157 & 100 & \multirow[t]{2}{*}{3.46} & \multirow[t]{2}{*}{$<0.001$} \\
\hline 4-everyday/week & 15 & 34.9 & 28 & 65.1 & 43 & 100 & & \\
\hline \multicolumn{9}{|l|}{ Sexual Orientation } \\
\hline Heterosexual & 116 & 63.0 & 68 & 37.0 & 184 & 100 & \multirow[t]{2}{*}{$25 \cdot 58$} & \multirow[t]{2}{*}{0.001} \\
\hline Homosexual & 1 & 6.3 & 15 & 93.7 & 16 & 100 & & \\
\hline \multicolumn{9}{|l|}{ Unsafe Sex Behavior } \\
\hline Safe & 89 & 89.9 & 10 & 10.1 & 99 & 100 & \multirow[t]{2}{*}{23.20} & \multirow[t]{2}{*}{$<0.001$} \\
\hline Unsafe & 28 & 27.7 & 73 & 72.3 & 101 & 100 & & \\
\hline \multicolumn{9}{|l|}{ Use of drugs injection } \\
\hline Yes & 1 & 10.0 & 9 & 90.0 & 10 & 100 & \multirow{2}{*}{14.11} & \multirow{2}{*}{0.001} \\
\hline No & 116 & 61.1 & 74 & 38.9 & 190 & 100 & & \\
\hline \multicolumn{9}{|l|}{ Geographical Location } \\
\hline Close to coast/port & 7 & 23.3 & 23 & 76.7 & 30 & 100 & \multirow[t]{2}{*}{6.02} & $<0.001$ \\
\hline Far from coast/port & 110 & 64.7 & 60 & $35 \cdot 3$ & 170 & 100 & & \\
\hline Perceived susceptibility & & & & & & & & \\
\hline High & 87 & 67.4 & 42 & 32.6 & 129 & 100 & 0.35 & 0.001 \\
\hline Low & 30 & 42.3 & 41 & $57 \cdot 7$ & 71 & 100 & & \\
\hline Perceived severity & & & & & & & & \\
\hline High & 56 & 57.1 & 42 & 42.9 & 98 & 100 & 0.06 & $<0.001$ \\
\hline Low & 61 & 59.8 & 41 & 40.2 & 102 & 100 & & \\
\hline Perceived threat & & & & & & & & \\
\hline High & 66 & 62.9 & 39 & 37.1 & 105 & 100 & 0.68 & 0.189 \\
\hline Low & 51 & 53.7 & 44 & 46.3 & 95 & 100 & & \\
\hline Self-Efficacy & & & & & & & & \\
\hline High & 33 & 16.5 & 36 & 18.0 & 69 & 100 & 1.95 & 0.026 \\
\hline Low & 84 & 42.0 & 47 & 23.5 & 131 & 100 & & \\
\hline
\end{tabular}

\section{Bivariate Analysis}

Table 3 showed the results of bivariate analysis. Table 3 showed that the risk of HIV/AIDS increased with age $\geq 36$ years $(\mathrm{OR}=1.43 ; \mathrm{p}=0.214)$, female $(\mathrm{OR}=1.04 ; \mathrm{p}=$ $0.886)$, sexual frequency 4 times per day $(\mathrm{OR}=3.46 ; \mathrm{p}<0.001)$, homosexual $(\mathrm{OR}=$ 25.58; $\mathrm{p}=0.001)$, unsafe sex behavior $(\mathrm{OR}=$ 23.20; $\mathrm{p}<0.001)$, injecting drug use $(\mathrm{OR}=$ 14.11; $\mathrm{p}=0.001)$, residents near coastal $(\mathrm{OR}=6.02 ; \mathrm{p}<0.001)$, low perceived susceptibility $(\mathrm{OR}=0.35 ; \mathrm{p}=0.001)$, high perceived severity $(\mathrm{OR}=0.06 ; \mathrm{p}<0.001)$, low perceived threat $(\mathrm{OR}=0.68 ; \mathrm{p}=0.189)$, and low self-efficacy $(\mathrm{OR}=1.95 ; \mathrm{p}=0.026)$.

\section{Path Analysis}

\section{a. Model Specification}

Model specifications were used to describe the variables to be studied. Exogenous variables consisted of age, gender, social capital, and geographical location. Endogenous variables included perceived susceptibility, perceived severity, self-efficacy, perceived threat, frequency of sexual intercourse, sexual orientation, injection drug 
Journal of Health Promotion and Behavior (2019), 4(1): 43-54

https://doi.org/10.26911/thejhpb.2019.04.01.05

abuse, unsafe sex behavior, and HIV infection.

\section{b. Model Identification}

The calculation of degree of freedom (df):

1) Measured variable :13

2) Endogenous variable : 9

3) Exogenous Variable : 4

4) Total of parameter : 13

$\mathrm{Df}=$ (measured variable) $\mathrm{x}$ (total of measured variable +1 ) / $2-$ (endogenous variabel + exogenous variable + total of parameter $)=(13 \times 14) / 2-(9+4+13)$

$=91-26$

$=65$

The result of the degree of freedom (df) was 65 meaning that over identified or path analysis can be done.

Table 4 showed the results of path analysis. HIV/AIDS was directly and positively associated with frequency of sexual intercourse, sexual behavior, sexual orientation, and injection drug abuse.
Sexual intercourse $>4$ times per day had logodd to experience HIV/AIDS 1.23 higher than sexual intercourse $<3$ times per day $(b=1.23 ; 95 \% \mathrm{CI}=0.27$ to $2.19 ; \mathrm{p}=$ o.012).

Injection drug use increased logodd HIV/AIDS infection 2.19 units $(b=2.19$; 95\% CI= 0.01 to $4.37 ; \mathrm{p}=0.049$ ).

Unsafe sex behavior increased logodd HIV/AIDS infection 3.10 units and it was statistically significant $(b=3.10 ; 95 \% \mathrm{CI}=$ 2.21 to 3.99 ; $\mathrm{p}<0.001$ ).

Homosexual increased logodd HIV/ AIDS infection 3.69 units and it was statistically significant $(\mathrm{b}=3.69$; CI95\% $=1.35$ to $6.04 ; \mathrm{p}=0.002$ ).

HIV/ AIDS infection was indirectly affected by perceived threat, social capital, residence, perceived susceptibility, perceived severity, self-efficacy, and age.

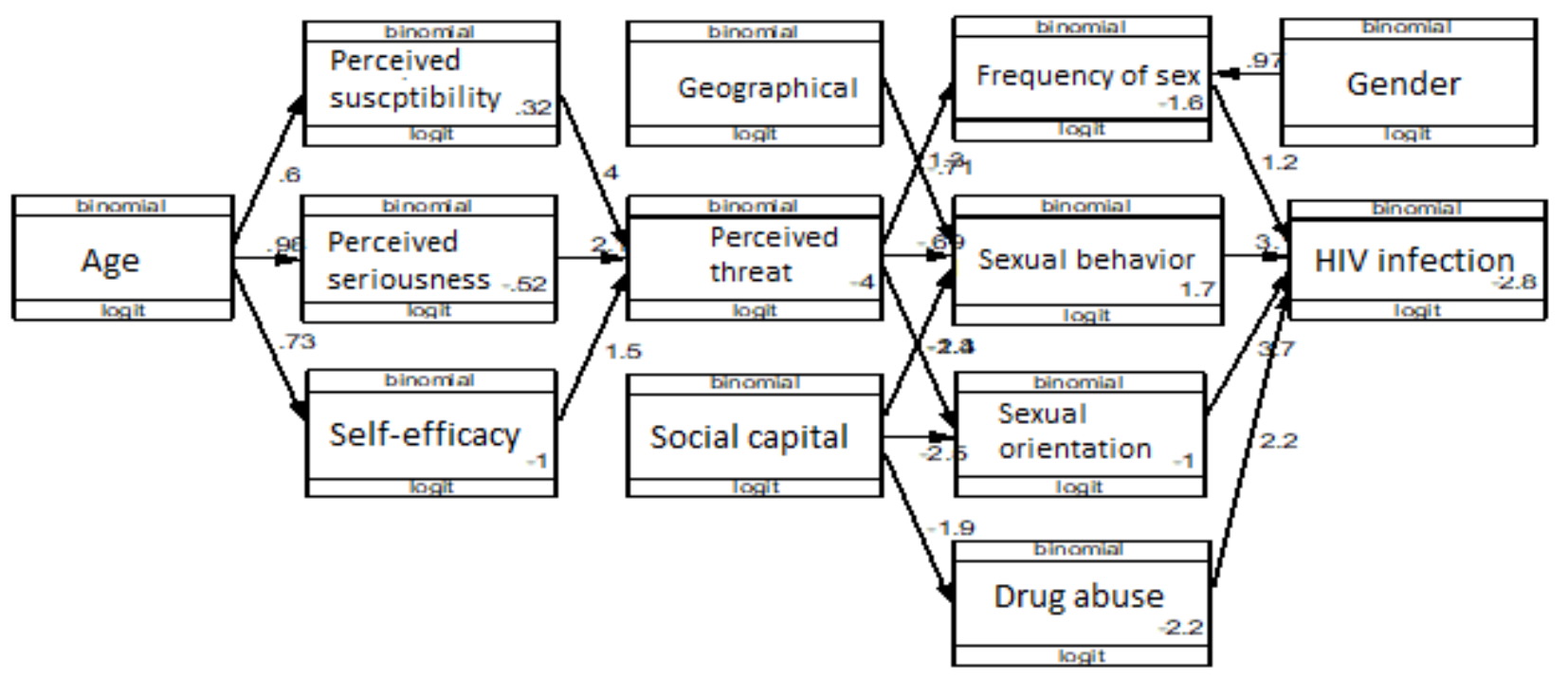

Figure 1. Path analysis model with estimation

\section{DISCUSSION}

\section{The effect of age on HIV / AIDS}

The results of the analysis showed that there was an indirect positive influence between the age variables with HIV / AIDS infection and statistically significant. The results of this study are in line with the research of Amelia et al. (2016) which states that the age group is statistically a factor associated with the incidence of HIV / AIDS. Subjects aged 28-44 years had a 3.9 times greater risk of HIV / AIDS compared with respondents aged 25-27 years. 
Other studies have shown similar results that research subjects aged $\geq 24$ years increased 4.33 times for HIV positive. The older a person will have behavior, lifestyle, and social interaction with many people. This can affect the increased risk of HIV infection (Subaeti et al., 2018).

Table 4. The results of path analysis

\begin{tabular}{|c|c|c|c|c|c|}
\hline \multirow[b]{2}{*}{ Dependent Variables } & \multirow[b]{2}{*}{ Independent Variable } & \multirow[b]{2}{*}{ b } & \multicolumn{2}{|c|}{ CI (95\%) } & \multirow[b]{2}{*}{$\mathbf{p}$} \\
\hline & & & $\begin{array}{l}\text { Lower } \\
\text { Limit }\end{array}$ & $\begin{array}{l}\text { Upper } \\
\text { Limit }\end{array}$ & \\
\hline \multicolumn{6}{|l|}{ Direct Effect } \\
\hline \multirow[t]{4}{*}{ HIV/AIDS infection } & $\begin{array}{l}\leftarrow \text { Frequency of having sex } \\
(>4 \text { times per dav) }\end{array}$ & 1.23 & 0.27 & 2.19 & 0.012 \\
\hline & $\leftarrow$ Injection drug use & 2.19 & 0.01 & 4.37 & 0.049 \\
\hline & $\leftarrow$ Unsafe sex behavior & 3.10 & 2.21 & 3.99 & $<0.001$ \\
\hline & $\leftarrow$ Homosexual & 3.69 & 1.35 & 6.04 & 0.002 \\
\hline \multicolumn{6}{|l|}{ Indirect Effect } \\
\hline \multirow{5}{*}{$\begin{array}{l}\text { Frequency of having sex } \\
\text { (>4 times per day) } \\
\text { Unsafe sex behavior }\end{array}$} & $\leftarrow$ Perceived threat (high) & -0.71 & -1.42 & -0.01 & 0.049 \\
\hline & $\leftarrow$ Gender female) & 0.97 & 0.20 & 1.73 & 0.013 \\
\hline & $\leftarrow$ Perception of threat (high) & -0.69 & -1.35 & -0.02 & 0.043 \\
\hline & $\leftarrow$ Residence near port & 1.32 & 0.35 & 2.29 & 0.008 \\
\hline & $\leftarrow$ Social capital (high) & -2.38 & -3.08 & -1.67 & $<0.001$ \\
\hline Homosexual & $\leftarrow$ Perceived threat (high) & -1.31 & -2.52 & -0.09 & 0.034 \\
\hline Homosexual & $\leftarrow$ Social capital (tinggi) & -2.53 & -4.06 & -1.01 & 0.001 \\
\hline Perceived threat (high) & $\leftarrow$ Perceived severity (high) & 2.05 & 1.09 & 3.00 & $<0.001$ \\
\hline Perceived threat (high) & $\begin{array}{l}\leftarrow \text { Perceived susceptibility } \\
\text { (high) }\end{array}$ & 4.00 & 2.87 & 5.12 & $<0.001$ \\
\hline Perceived threat & $\leftarrow$ Self-Efficacy (high) & 1.48 & 0.52 & 2.43 & 0.002 \\
\hline Injection drug use & $\leftarrow$ Social capital (high) & -189 & -3.46 & -0.30 & 0.019 \\
\hline Perceived severity & $\leftarrow$ Age $(\geq 36$ years $)$ & 0.98 & 0.41 & 1.55 & 0.001 \\
\hline Perceived susceptibility & $\leftarrow$ Age $(\geq 36$ years $)$ & 0.60 & 0.01 & 1.19 & 0.046 \\
\hline Self-Efficacy (high) & $\leftarrow$ Age $(\geq 36$ years) & 0.73 & 0.14 & 1.33 & 0.016 \\
\hline \multicolumn{6}{|l|}{$\mathrm{N}$ Observation $=200$} \\
\hline \multicolumn{6}{|l|}{ Log likelihood $=-827.5$} \\
\hline \multicolumn{6}{|l|}{ AIC $=1709.0$} \\
\hline$=1790.1$ & & & & & \\
\hline
\end{tabular}

\section{The effect of gender on HIV / AIDS}

The results of the analysis showed that there was an indirect positive influence between gender and HIV / AIDS infection through the frequency of sexual relations.

The results of the study found that men aged 20-34 years were more likely to carry out higher-risk behaviors than women. Men, especially those aged 20-34 years, are more likely to have more than one partner and inconsistent use of condoms compared to women. Men are often unaware of HIV positive, making it easier to transmit HIV to many women who are partners (Huerga et al., 2017).
The results of other studies showed that the pattern of sexual relations in women as housewives had an effect on HIV/AIDS status, subjects with sexual relations patterns of multiple sex partners had a greater vulnerability compared to subjects with single sex partners (Laksana et al., 2017).

\section{The effect of frequency of sexual intercourse on HIV/AIDS}

The results of the analysis showed that there was a direct positive influence between the frequency of sex with the risk of HIV/AIDS infection. The frequency of sexual intercourse 4 times - every day / 
Journal of Health Promotion and Behavior (2019), 4(1): 43-54

https://doi.org/10.26911/thejhpb.2019.04.01.05

week had a higher risk of HIV / AIDS infection than the frequency of sexual intercourse 1-3 times / week.

The high frequency of sexual intercourse at risk of HIV was caused by the lack of consistent use of condoms and having more than one sexual partner. This is consistent with the results of study showing that HIV was obtained during receptive anal sex compared to vaginal sex and can increase the high burden of HIV for female sex workers. $15.9 \%$ of all sexual relations are anal. WPS generally have sex that is inconsistent in using condoms to facilitate transmission of HIV (Owen et al., 2019).

\section{The effect of sexual orientation on HIV / AIDS}

The results of the analysis showed that there was a direct positive influence between sexual orientation and the risk of HIV / AIDS.

Men who act as receptors during sexual intercourse with other men had a greater risk of being infected with HIV / AIDS. Men with an insertor role would penetrate with extreme actions that cause injury, inflammation, infection of the digestive tract, anal receptive partner, then continued anal sex without using a condom (Sidjabat et al., 2017).

Other research results suggest that homosexual HIV risk factors includeD contact with partner blood during sexual intercourse 3.7 more at risk of HIV infection, alcohol intake when sexual activity and condom use are inconsistent in receptive anal sex (Silva et al., 2014).

\section{The effect of unsafe sex behavior on HIV / AIDS}

The results of the analysis showed that there was a direct positive effect between unsafe sexual behavior and the risk of HIV / AIDS infection and was statistically significant.
A study by Murtono et al. (2018) states that combined sexual activity had 4.32 times the risk of HIV / AIDS compared to sexual activity without only oral, anal or vaginal. The use of condoms did not consistently have 5.34 risk of HIV / AIDS than consistent condom use and STI patients had a risk of 2.92 times.

A study by Wati et al. (2019) shows that the number of sexual partners increases the risk of HIV / AIDS is higher than those who have one sexual partner and do not use condoms.

\section{The effect of social capital on the risk of HIV / AIDS}

The results of the analysis showed that there was an indirect negative influence between social capital and HIV / AIDS infection through unsafe sexual behavior, injecting drug use and sexual orientation.

Individuals who had access to low levels of social capital were four times more likely to be HIV positive compared to people who have access to high social capital (Frumence et al., 2014).

Other studies also state that migrants tend to have lower levels of social capital and low socioeconomic status which increases the risk of HIV / AIDS (Sen et al., 2010).

\section{The effect of geographical location on the risk of HIV / AIDS}

The results of the analysis showed that there was an indirect positive relationship between geographical location and HIV / AIDS infection through unsafe sexual behavior.

Global maritime industries such as seafarers, fishing, ports and other land personnel had the risk of infection with sexually transmitted diseases including HIV. The proximity of prostitution and the large population of sex workers, as well as the fact that many sexually active young seafarers are a compound problem and 
increase the danger of HIV infection (Ogboghodo et al., 2016).

The location of a residence near a port or coast was more easily infected with HIV due to access to a localization site and a large population of WPS around the port and the large number of entrants coming in and out of the port.

\section{The effect of injection drug use on HIV / AIDS}

The results of path analysis showed that there was a direct positive influence between injecting drug use and the risk of HIV / AIDS infection.

Men who consume drugs before having sex are 10 times more likely to have unprotected sex (Don et al., 2012). The results of this study are in line with $\mathrm{Yu}$ et al. (2017) that the frequency of drug injections has a significant effect on HIV, men who use injecting drugs are 9 times more likely to be HIV positive.

\section{The effect of perceived susceptibi- lity on HIV / AIDS}

The results of path analysis showed that there was an indirect positive relationship between perceptions of vulnerability with HIV/AIDS infection through perceived threat. High perceptions of vulnerability would increase 4 times the perception of threats compared to perceptions of low vulnerability. Therefore, the perception of a high threat about HIV / AIDS would reduce behavior which could increase the risk of HIV / AIDS infection.

Perceived susceptibility improve the prevention behavior of HIV/AIDS transmission. The results of the study stated that perceptions of road construction workers who feel vulnerable to HIV are more twice as consistent in using condoms than those who feel less vulnerable (Tarkang, 2018).

\section{The effect of perceived serious- ness on HIV / AIDS}

The path analysis results showed that there was an indirect positive relationship between the perception of seriousness with HIV/AIDS infection through the perception of threats. A high perception of the seriousness of the disease would increase the perception of the threat to the disease.

The results of other studies showed a significant perception of severity with STI prevention behavior. Commercial sex workers with a perception of high severity are likely 4.02 times more likely to have healthy behavior in preventing STIs (Wulandari et al., 2017).

\section{The Effect of perceived threats on the risk of HIV / AIDS}

The results of path analysis showed that there was an indirect negative relationship between perceived threat and HIV / AIDS infection through the frequency of relationships, unsafe sexual behavior and sexual orientation.

Perceived susceptibility and severity that was felt was a perceived threat of the situation, which was characterized by contracting certain diseases. Current studies referred to the perceived threat to $\mathrm{HIV} /$ AIDS infection. The perceived threat or perceived risk can motivate to avoid threats (Tarkang, 2018).

\section{The effect of self-efficacy on the risk of HIV / AIDS}

The results of the analysis showed that there was an indirect positive relationship between self-efficacy and HIV/AIDS infection through the perception of threats.

Self-confidence about people's capacities influenced how they behaved. So that self-efficacy affects the success of someone using a condom to prevent the risk of HIV / AIDS (Tarkang, 2018).

This study is also in line with the study conducted by Wulandari et al. (2017) 
Journal of Health Promotion and Behavior (2019), 4(1): 43-54

https://doi.org/10.26911/thejhpb.2019.04.01.05

stating that female commercial sex workers with strong self-confidence have 7.32 times greater ability to have healthy behavior in the prevention of sexually transmitted diseases.

\section{AUTHORS CONTRIBUTION}

Ita Fijanah Puspita, the main researcher played a role in collecting and processing the data; Uki Retno Budihastuti, reviewed the manuscript; Vitri Widyaningsih, examined the conceptual framework and methodology.

\section{FUNDING AND SPONSORSHIP}

The author used her own money to conduct the study.

CONFLICT OF INTEREST

There was no conflict of interest in this study.

\section{ACKNOWLEDGEMENT}

Authors would like to thank the Jepara District Health Office in Central Java and the Indonesian Positive Women Association and the Jepara Plus Foundation which have helped in many ways.

\section{REFERENCE}

$\overline{\text { Amelia M, Hadisaputro S, Laksono B, Anies }}$ A (2016). Faktor risiko yang berpengaruh terhadap kejadian HIV/AIDS pada laki-laki umur 25 - 44 tahun di Kota Dili, Timor Leste (Risk factors that influence the incidence of HIV / AIDS in men aged 25-44 years in the city of Dili, Timor Leste). Jurnal Epidemiologi Kesehatan Komunitas, 1(1): 39-46. doi: 10.14710/J.E.K.K.V1I1.396o.

Cené CW, Akers AY, Lloyd S W, Albritton T, Powell HW, Corbie G (2011). Understanding social capital and HIV risk in rural African American cmmunities. Journal of General Internal Medicine, 26(7): 737-744. doi: 10.1007/s11606011-16464.

Dinas Kesehatan Kabupaten Jepara (2018). Data HIV Kabupaten Jepara.

Don O, Carla DS, Emily A (2012). Sexual risk and substance use behaviors among African men who have sex with men and women. Journal AIDS, 15(3):576-583. doi: 10.1007/s10461o09-9588-0.

Frumence G, Emmelin M, Eriksson M, Kwesigabo G, Killewo J, Moyo S, Nystrom L (2014). Access to social capital and risk of HIV infection in Bukoba urban district, Kagera region, Tanzania. Archives of Public Health, 72(1):1-11. doi: 10.1186/2049-325872-38.

Gemechu B, Gerbi, Tsegaye H, Vinaida R, David (2013). Psychosocial factors as predictors of HIV/AIDS risky behaviors among people living with HIV/AIDS, 71(2): 233-236. doi: 10.1038/mp.2011.182.doi.

González RP, Kadengye DT, Mayega RW (2019). The knowledge riskbehaviour continuum among young Ugandans: what it tells us about SRH/HIV integration. BMC Public Health, 19(1): 110. doi: 10.1186/s12889-0 9-6809-y.

Huerga H, Venables E, Ben-Farhat J, Van Cutsem G, Ellman T, Kenyon C (2017). Higher risk sexual behaviour is associated with unawareness of HIV-positivity and lack of viral suppression Implications for Treatment as Prevention. Scientific Reports, 7(1): 6-12. doi: 10.1038/s41598-017-16382-6.

International Labour Office (2018). The impact of HIV and AIDS on the world of work: Global estimates. Retrieved from https://www. ilo.org /wcmsp5/groups/public. 
Laksana B, Demartoto A, Indarto D (2017). Knowledge, attitude, sexual behavior, family Support, and their associations with HIV/AIDS Status in Housewives. Journal of Epidemiology and Public Health, 2(2): 154-163. doi: 10.26911/jepublic health.2017.02.02.06.

Murtono D, Riyanto P, Shaluhiyah $\mathrm{Z}$. (2018). Influential host factors to the incidence of HIV/AIDS in key populations in Pati District. Kesmas: National Public Health Journal, 13(1): 1722. doi: 10.21109/kesmas.v13i1.1463.

Ogboghodo EO, Ali EN, Okojie OH (2016). Prevalence and determinants of HIV infection among maritime workers in a Nigerian seaport. Journal of Community Medicine and Primary Health Care, 28(2): 94-100. Retrieved from https://www.ajol.info/index.php/jcm phc/article/download/154700/144283.

Owen BN, Baggaley RF, Elmes J, Harvey A, Shubber Z, Butler AR, Boily MC (2019). What proportion of female sex workers practise anal intercourse and how frequently? A Systematic Review and Meta-analysis. Journal AIDS and Behavior, (123456789). doi: 10.1007/s10461-019-02477-w.

Ransome Y, Thurber KA, Swen M, Crawford ND, German D, Dean LT (2018). Social capital and HIV/AIDS in the United States: Knowledge, gaps, and future directions. SSM - Population Health, 5(3): 73-85. doi: 10.1016/j.ssmph.2018.05.007.

Sen S, Aguilar JP, Goldbach J (2010). Does social capital act as a buffer against HIV risk among migrant men in subsaharan Africa? Journal of HIV/AIDS and Social Services, 9(2): 190-211. doi: 10.1080/153815010 795790.

Sidjabat FN, Setyawan H, Sofro MA, Hadisaputro S (2017). Men who have sex with men, HIV and their sexual behaviour in Semarang. Journal Kespro, 8(2): 131-142. doi: 10.22435/kespro.v8i2.6753.131-142

Silva AP, Greco M, Fausto MA, Greco DB, Carneiro M (2014). Risk factors associated with HIV infection among male homosexuals and bisexuals followed in an open cohort study: project Horizonte, Brazil (1994-2010). PLoS ONE, 9(10): 3-10. doi: 10.1371/journal.pone.0109390.

Sionean C, Le BC, Hageman K, Oster AM, Wejnert C, Hess KL, study group; C. for D. C. and P. (CDC) (2014). HIV risk, prevention, and testing behaviors among heterosexuals at increased risk for HIV infection-National HIV behavioral surveillance system, 21 U.S. cities, 2010. Surveillance Summaries, 1-39. Retrieved from https://www.ncbi.nlm.nih.gov/pubmed/25522191.

Subaeti T, Demartoto A, Murti B (2018). Socioeconomic factors and sexual behavior associated with HIV infection in population, in Kebumen District, Central Java. Journal of Health Promotion and Behavior, 3(1): 56-65. doi: 10.26911/thejhpb.2018.03.01.06.

Tarkang E, Pencille LB (2018). Psychosocial predictors of consistent condom use among migrant road construction workers in the southwest region of Cameroon using the health belief model. Pan African Medical Journal, 29: 1-12. doi: 10.11604/pamj.2018.29.215.15130.

Wati EE, Lubis R, Rochadi RK (2019). The effects of multiple sexual partners and condoms use on the incidence of HIV in men having sex with men. Journal of Health Promotion and Behavior, 3(3): 150-154. doi: 10.26911/the jhpb.2018.03.03.02.

WHO (2018). Data and Statistic. Retrieved 
Journal of Health Promotion and Behavior (2019), 4(1): 43-54

https://doi.org/10.26911/thejhpb.2019.04.01.05

from https://www.who.int/hiv/data/en/.

Wulandari Y, Suryani N, Pamungkasari EP (2017). Health Belief Model: Health preventive behavior of sexually transmitted infection in female sex workers in Surakarta. Journal of Health Promotion and Behavior, 1(2): 70-78. doi: 10.26911/thejhpb.2016.01.02.02. Yu D, Dixit S, Subedi B, Shrestha S, Santangelo SL, Link C (2017). A study of the prevalence and risk factors leading to HIV infection among a sample of street children and youth of Kathmandu. Journal Harvard community .1-7. doi: 10.1186/1742-6405-9-25. 